\title{
Effects of arbuscular mycorrhizae on growth and mineral nutrition of greenhouse propagated fruit trees from diverse geographic provenances
}

\author{
Tiby Guissou $\dagger^{(1)}$, Amadou Hamadoun Babana ${ }^{(2)}$, Kadidia Bibata Sanon ${ }^{(1)}$, \\ Amadou Moustapha Ba ${ }^{(3)}$
}

(1) Centre National de Recherche Scientifique et Technologique / Institut de l'Environnement et de Recherches AgricolesDépartement Productions Forestières (CNRST/INERA-DPF). Laboratoire de Microbiologie. 03 BP 7047 Ouagadougou 03 (Burkina Faso).E-mail: sbkady@gmail.com

(2) Université des Sciences, des Techniques et des Technologies de Bamako. Faculté des Sciences et Technologies. Laboratoire de Recherche en Microbiologie et de Biotechnologie microbienne. BP E3206. Bamako (Mali).

(3) Université des Antilles et de la Guyane. Faculté des Sciences exactes et naturelles. Laboratoire de Biologie et Physiologie végétales. BP 592. FR-97150 Pointe-à-Pitre (Guadeloupe, France).

Received on October 8, 2014; accepted on February 19, 2016.

Description of the subject. Arbuscular mycorrhizal (AM) fungi are known to promote plant growth by enhancing mineral uptake in nutrient deficient soils. These beneficial effects on plant growth may vary considerably between cultivars of a given species and between plant species originating from different locations.

Objectives. The present experiment evaluated the response of three Sahelian fruit trees: néré (Parkia biglobosa [Jacq.] G.Don), tamarind (Tamarindus indica L.), and jujube (Ziziphus mauritiana Lam.), originating from five different geographic provenances, to mycorrhizal colonization, evaluate their respective mycorrhizal dependency (MD) and analyze their leaf and stem mineral composition.

Method. Trees were cultivated in a nursery on pre-sterilized soil substrate low in available P $\left(2.18 \mu \mathrm{g} \cdot \mathrm{g}^{-1}\right)$ with or without inoculum of Glomus aggregatum (Schenck \& Smith emend. Koske). The experiment was arranged in a factorial design for each fruit tree species separately: 5 provenances $\times 2$ AM treatments (inoculated and non-inoculated [control]) with 10 replicates per treatment. Plants were harvested six months after inoculation and different parameters were measured.

Results. Overall, the results showed significant provenance variations in the plant response to mycorrhizal inoculation. Néré mycorrhizal plants, from two seed sources, tamarind and jujube plants from one seed source had significant higher dry weight and shoot height than those from other provenances. Jujube plants from 3 out of the 5 provenances showed significant higher MD. It then appears that seed provenance happened to be determinant even though AM-root colonization levels (80-90\%) do not vary much from one provenance to another. In all cases, the fruit trees benefited from AM fungi with increased $\mathrm{N}$, $\mathrm{P}$ and $\mathrm{K}$ mineral uptake in aerial parts. In particular P uptake was proportional to MD concentration in AM-jujube plants.

Conclusions. These results demonstrate the importance of considering seed provenance when performing pre-selection of mycotrophic plant candidates prior to large-scale fruit tree propagation in orchards and agroforestry systems.

Keywords. Glomus aggregatum, mycorrhization, fruit trees, provenance, environment, greenhouse crops, Sahel.

Effets des mycorhizes à arbuscules sur la croissance et la nutrition minérale d'arbres fruitiers de provenances géographiques diverses cultivés en serre

Description du sujet. Les champignons mycorhiziens à arbuscules (CMA) améliorent la croissance et la nutrition minérale des plantes, notamment sur sols pauvres en minéraux. Ces effets bénéfiques pourraient varier considérablement entre cultivars d'une espèce de plante donnée et entre espèces de plantes provenant de différentes localités.

Objectifs. La présente expérience se propose d'évaluer la dépendance mycorhizienne (DM), la colonisation racinaire et la composition minérale des parties aériennes de cinq provenances géographiques de trois arbres fruitiers sahéliens, le néré (Parkia biglobosa [Jacq.] G.Don), le tamarinier (Tamarindus indica L.) et le jujubier (Ziziphus mauritiana Lam.).

Méthode. Les plants ont été cultivés sur un sol déficient en P assimilable $\left(2,18 \mu \mathrm{g} \cdot \mathrm{g}^{-1}\right)$, inoculés ou non avec un isolat de Glomus aggregatum (Schenck \& Smith emend. Koske) en pépinière. Le dispositif expérimental est de type factoriel pour 
chaque espèce fruitière prise séparément : 5 provenances x $2 \mathrm{MA}$ (Mycorhizes arbusculaires, inoculé et non-inoculé [témoin]) avec 10 répétitions par traitement. Les plants ont été récoltés six mois après inoculation et les différents paramètres mesurés.

Résultats. En général, les résultats montrent que la mycorhization entraine des variations significatives dans la réponse des plantes selon leur provenance pour chaque arbre fruitier. Une augmentation significative de la hauteur et de la masse sèche totale du néré de deux provenances et de celle du tamarinier et du jujubier d'une provenance a été enregistrée. Des DM significativement plus élevées ont été obtenues avec le jujubier pour 3 provenances sur 5. La DM varie également en fonction de la provenance des semences, bien que le taux de mycorhization (80-90\%) demeure toujours élevé. Globalement, les plantes bénéficient des CMA par une augmentation significative en $\mathrm{N}$, $\mathrm{P}$, et $\mathrm{K}$, et les taux d'absorption des minéraux, en particulier le $\mathrm{P}$, étant proportionnel à la DM particulièrement chez les jujubiers mycorhizés.

Conclusions. Ces résultats indiquent l'importance de considérer la provenance des semences dans la présélection de plantes à croissance rapide et à DM élevée pour la production fruitière en vergers ou dans des systèmes agroforestiers.

Mots-clés. Glomus aggregatum, mycorhization, arbre fruitier, provenance, environnement, plante de serre, Sahel.

\section{INTRODUCTION}

Sahelian countries are facing rapid degradation of natural resources resulting in dramatic reduction in soil fertility and provision of food and other ecosystem services. Fruit trees are traditionally and intensively exploited by local people for fruits, seeds, fodder and medicines (Ambé, 2001). They contribute to food security as they help overcome nutritional problems, and are an important source of revenue for smallholder farmers (Atangana et al., 2001; Akinnifesi et al., 2004; Leakey et al., 2005). For their high nutritive and economic added value, fruit trees are often alternative crops, both in agroforestry systems and in orchards, and as such have become a priority in agronomic research efforts (Leakey et al., 2005; Akinnifesi et al., 2006; Franzel et al., 2007).

Among the fruit tree species well adapted to arid and semi-arid regions and commonly used by farmers, néré (Parkia biglobosa [Jacq.] G.Don), tamarind (Tamarindus indica L.) and jujube (Ziziphus mauritiana Lam.), three multipurpose fruit trees from West Africa are the most popular. These fruit trees grow slowly in West African soils due to different factors amongst which nutrient deficiency, particularly $\mathrm{P}$, and erratic rainfalls (Querejeta et al., 2003; Lynch, 2007) have the most impact. Under such conditions, fruit trees largely rely upon arbuscular mycorrhizal (AM) fungi for growth and nutrient uptake (Mathur et al., 2000; Guissou et al., 2001; Kung'u et al., 2008; Fitter et al. 2011; Smith et al., 2011). Arbuscular mycorrhizal establishment extends plant root system's capacity to explore more water resources in soil and to cope with stress situations (Mathur et al., 2000; Guissou et al., 2001; Manoharan et al., 2010). Furthermore, prophylactic effects have been often reported, proving in many situations that AM fungi can act as biological control agents by lessening proliferation and damage caused by pests, insects and soil-borne diseases (St-Arnaud et al., 2005; Chandra et al., 2010; Ozgonen et al., 2010; Jung et al., 2012). The inoculation of 13 fruit trees with an efficient AM fungus isolate, Glomus aggregatum Schenck \& Smith emend. Koske, or with a non-efficient AM fungus isolate, Glomus intraradices Schenck \& Smith, showed that the jujube fruit tree responded better to the AM inoculation in comparison to the other fruit trees regardless of the AM fungus used as inoculum (Guissou et al., 1998; Bâ et al., 2000). These data on mycorrhizal dependency (MD) and mineral nutrition potential have been focused on a single provenance for néré, tamarind and jujube fruit trees even though the benefits of AM fungi on plant growth could vary widely between plant species, and even between cultivars or species from different geographic provenances (Lesueur et al., 2005; Plenchette et al., 2005; Belay et al., 2013; Sousa et al., 2013). In order to verify the level of variability between néré, tamarind or jujube plants originating from different geographical origins, each of these fruit trees was inoculated or not inoculated with an efficient AM fungus strain of Glomus aggregatum. Comparative analyses of nutrient uptake and MD measurements were performed on greenhouse propagated species grown in a P-deficient soil. Results are discussed taking into consideration genetic diversity in tree species and provenance influences to optimize large-scale fruit tree production in agroforestry systems.

\section{MATERIALS AND METHODS}

\subsection{Plants}

Plants were propagated on a P-deficient sandy soil collected at $0-20 \mathrm{~cm}$ depth under a stand of Afzelia africana Sm. \& Pers. at Dindéresso (South Sudanian zone of Burkina Faso, at $11^{\circ} 13^{\prime} \mathrm{N}$ Latitude, $4^{\circ} 26^{\prime} \mathrm{W}$ Longitude, and $339 \mathrm{~m}$ Altitude, $950 \mathrm{~mm}$ annual rainfall). The soil was sieved $(2 \mathrm{~mm})$ and sterilized by autoclaving $\left(120^{\circ} \mathrm{C}\right.$ for $\left.1 \mathrm{~h}\right)$ to eliminate native microflora prior to use. The soil characteristics after autoclaving were: $6.7 \%$ clay, $6.5 \%$ silt, $86.6 \%$ sand, $0.6 \%$ organic matter, $0.3 \%$ total Carbon (C), $0.05 \%$ Nitrogen $(\mathrm{N}), \mathrm{C} / \mathrm{N}$ ratio of $7,98 \mu \mathrm{g} . \mathrm{g}-1$ total $\mathrm{P}$, 
$2.18 \mu$ g.g-1 P-Bray 1, pH (1:2, soil/water ratio) 7.4, and $\mathrm{pH}(1: 2$ soil $/ \mathrm{KCl}$ ratio) 6.8 .

Seeds of each fruit tree species collected from five different geographic locations in Burkina Faso and Senegal (Table 1) were purchased from Centre National de Semences Forestières (CNSF, Burkina Faso) and Institut Sénégalais de Recherches Agricoles/ Direction de Recherches et de Productions Forestières (ISRA/DRPF, Senegal).

\subsection{Mycorrhizal fungus}

The AM fungus isolate used in this experiment was Glomus aggregatum Schenck \& Smith emend. Koske (isolate IR 27) isolated from a rhizosphere of Acacia mangium Willd. at Dinderesso in Burkina Faso. The fungus was propagated on maize plants (Zea mays L.) grown in pot cultures for 4 months. The AM inoculum consisted of a mixture of sand, spores, hyphae and infected maize root fragments. Twenty g of inoculum, containing approximately 103 infected propagules
(Guissou et al., 1998) were added to each pot-culture. Non-inoculated (control) pots received the same amount of autoclaved inoculum $\left(120^{\circ} \mathrm{C}\right.$ for $\left.20 \mathrm{~min}\right)$ with $10 \mathrm{ml}$ of inoculum water extract collected by vacuum filtration system.

\subsection{Pot experiment}

The seeds were surface scarified and sterilized by immersion in $95 \%$ sulphuric acid for $30 \mathrm{~min}$, $45 \mathrm{~min}$, and $10 \mathrm{~min}$ for néré, tamarind, and jujube, respectively. The sterilized seeds of these three plant species were rinsed several times in sterile distilled water for $24 \mathrm{~h}$ and then aseptically pre-germinated on moist sterilized cotton in Petri dishes at $30{ }^{\circ} \mathrm{C}$ until the radicles appeared. Once germinated, they were selected for uniformity before sowing one seedling per cylindrical plastic pot $(24 \mathrm{~cm}$ height $\times 7.5 \mathrm{~cm}$ diameter). The pots were watered to field capacity and maintained at that moisture level by weighing the pots in the morning and in the afternoon and replenishing

Table 1. Geographical and climatic characteristics of seed provenance locations for the seeds of the three fruit tree species used - Caractéristiques géographiques et climatiques des localités de provenances des graines chez les trois espèces d'arbres fruitiers utilisés.

\begin{tabular}{|c|c|c|c|c|c|c|c|}
\hline Fruit tree species & $\begin{array}{l}\text { Country of seed } \\
\text { provenance }\end{array}$ & $\begin{array}{l}\text { Seed collection } \\
\text { site }\end{array}$ & $\begin{array}{l}\text { Altitude } \\
(\mathrm{m})\end{array}$ & Longitude & Latitude & $\begin{array}{l}\text { Climatic } \\
\text { zone }\end{array}$ & $\begin{array}{l}\text { Rainfall } \\
\left(\mathrm{mm} \cdot \mathrm{an}^{-1}\right)\end{array}$ \\
\hline \multirow[t]{5}{*}{$\begin{array}{l}\text { Néré } \\
\text { (Parkia biglobosa) }\end{array}$} & \multirow[t]{3}{*}{ Burkina Faso } & Bazèga & 335 & $01^{\circ} 26^{\prime} \mathrm{W}$ & $11^{\circ} 58^{\prime} \mathrm{N}$ & $\begin{array}{l}\text { Sudano- } \\
\text { sahelian }\end{array}$ & $600-900$ \\
\hline & & Bankartougou & 249 & $00^{\circ} 44^{\prime} \mathrm{E}$ & $12^{\circ} 56^{\prime} \mathrm{N}$ & $\begin{array}{l}\text { Sudano- } \\
\text { sahelian }\end{array}$ & $600-900$ \\
\hline & & Soumousso & 322 & $04^{\circ} 03^{\prime} \mathrm{W}$ & $11^{\circ} 01^{\prime} \mathrm{N}$ & Sudanian & $900-1,200$ \\
\hline & \multirow[t]{2}{*}{ Senegal } & Diégoune & 6 & $16^{\circ} 22^{\prime} \mathrm{W}$ & $12^{\circ} 50^{\prime} \mathrm{N}$ & Sudanian & $900-1,000$ \\
\hline & & Néma & 3 & $16^{\circ} 17^{\prime} \mathrm{W}$ & $13^{\circ} 04^{\prime} \mathrm{N}$ & $\begin{array}{l}\text { Sudano- } \\
\text { guinean }\end{array}$ & $800-1,000$ \\
\hline \multirow[t]{5}{*}{$\begin{array}{l}\text { Tamarind } \\
\text { (Tamarindus indica) }\end{array}$} & \multirow[t]{3}{*}{ Burkina Faso } & Comin-Yanga & 271 & $00^{\circ} 08^{\prime} \mathrm{E}$ & $11^{\circ} 42^{\prime} \mathrm{N}$ & $\begin{array}{l}\text { Sudano- } \\
\text { sahelian }\end{array}$ & $600-900$ \\
\hline & & Kongoussi & 313 & $01^{\circ} 31^{\prime} \mathrm{W}$ & $13^{\circ} 19^{\prime} \mathrm{N}$ & Sahelian & $300-600$ \\
\hline & & Sondogtenga & 314 & $01^{\circ} 48^{\prime} \mathrm{W}$ & $12^{\circ} 35^{\prime} \mathrm{N}$ & $\begin{array}{l}\text { Sudano- } \\
\text { sahelian }\end{array}$ & $600-900$ \\
\hline & \multirow[t]{2}{*}{ Senegal } & Foundiougne & 3 & $16^{\circ} 28^{\prime} \mathrm{W}$ & $14^{\circ} 07^{\prime} \mathrm{N}$ & Sudanian & $900-1,000$ \\
\hline & & Tiénaba & 35 & $16^{\circ} 47^{\prime} \mathrm{W}$ & $14^{\circ} 45^{\prime} \mathrm{N}$ & $\begin{array}{l}\text { Sahelo- } \\
\text { sudanian }\end{array}$ & $400-600$ \\
\hline \multirow[t]{5}{*}{$\begin{array}{l}\text { Jujube } \\
\text { (Ziziphus mauritiana) }\end{array}$} & \multirow[t]{2}{*}{ Burkina Faso } & Gonsé & 274 & $01^{\circ} 18^{\prime} \mathrm{W}$ & $12^{\circ} 23^{\prime} \mathrm{N}$ & $\begin{array}{l}\text { Sudano- } \\
\text { sahelian }\end{array}$ & $600-900$ \\
\hline & & Léri & 272 & $03^{\circ} 23^{\prime} \mathrm{W}$ & $12^{\circ} 46^{\prime} \mathrm{N}$ & Sudanian & $900-1,000$ \\
\hline & \multirow[t]{3}{*}{ Senegal } & Bandia & 37 & $17^{\circ} 02^{\prime} \mathrm{W}$ & $14^{\circ} 37^{\prime} \mathrm{N}$ & $\begin{array}{l}\text { Sahelo- } \\
\text { sudanian }\end{array}$ & $400-600$ \\
\hline & & Columba & 7 & $15^{\circ} 38^{\prime} \mathrm{W}$ & $13^{\circ} 45^{\prime} \mathrm{N}$ & Sudanian & $900-1,000$ \\
\hline & & Dahra & 40 & $15^{\circ} 28^{\prime} \mathrm{W}$ & $15^{\circ} 20^{\prime} \mathrm{N}$ & $\begin{array}{l}\text { Sahelo- } \\
\text { sudanian }\end{array}$ & $400-600$ \\
\hline
\end{tabular}


the water used (i.e. difference between morning and afternoon weights).

The experiment was arranged in a factorial design with two factors for each fruit tree species separately: 5 provenances $\times 2$ AM treatments (inoculated and non-inoculated [control]). Each of the 10 treatments was set-up in a completely randomized design with 10 replicates for each treatment combination, for a total of 100 plants for each fruit tree species. The experiment was conducted under nursery conditions and plants were grown under natural light (day length approximately $12 \mathrm{~h}$ ), mean temperature at approximately $35^{\circ} \mathrm{C}$ day.

\subsection{Harvest and chemical analysis}

Plant shoots and roots were harvested separately six months after inoculation. Shoot height, total dry weight (TDW), and root/shoot ratio were measured. Plant material was dried in an oven at $70{ }^{\circ} \mathrm{C}$ for seven days and weighed. The compound leaves (leaf blade, petiole, and rachis) were analyzed for the $\mathrm{N}, \mathrm{P}$ and $\mathrm{K}$ concentrations. Mycorrhizal dependency (MD) of each provenance of fruit trees was determined by expressing the difference between the TDW of AM plants and the TDW of non-AM plants as a percentage of the TDW of AM plants (Plenchette et al., 1983). To identify the AM fungal colonization rate, randomly sampled roots were collected from each plant, carefully washed with tap water and deionised water to remove adhering soil particles, cut into $1-\mathrm{cm}$ long fragments, and cleared for $1 \mathrm{~h}$ in $10 \% \mathrm{KOH}$ at $80^{\circ} \mathrm{C}$. The cleared roots were then stained with $10 \%$ Trypan blue (Phillips et al., 1970). A total of $100,1-\mathrm{cm}$ root pieces per plant were randomly selected, mounted on microscopic slides and examined for colonization patterns (40X magnification) using a compound microscope fitted with an eyepiece scale. The AM colonization rate was the colonization intensity calculated as length of cortical cells colonized (in mm) by the AM fungi for each root fragment expressed as a percentage of total root length colonized (Mc Gonigle et al., 1990; Declerck et al., 1996). The P and $\mathrm{N}$ concentrations in compound leaves were determined by the molybdate blue method (Murphy et al., 1962) and colorimetry method after Kjeldahl digestion, respectively. The K concentration in compound leaves was determined by means of atomic absorption spectrophotometry (John, 1970).

\subsection{Data analysis}

For each fruit tree species, all data were subjected to two-factor analysis of variance (provenance $\mathrm{x}$ AM treatment) using the general linear models procedure of SAS (1990). A threshold of 5\% was considered statistically significant. Means of parameters with significant $\mathrm{F}$ were compared by using the Fisher protected least significance difference (LSD) test (Steel et al., 1980).

\section{RESULTS}

The analysis of variance revealed that for the interactions between provenance and AM treatments the level of significance for the measured parameters varied according to fruit trees (Tables 2, 3 and 4). The results showed that in each of the three fruit tree species, no AM formation was observed in noninoculated plants regardless of the provenance, thus indicating that no contamination occurred between the different treatments (Table 5).

\subsection{Influence of néré seed provenances on AM response}

Néré plants inoculation with the G.aggregatum isolate significantly increased the shoot growth of of plants from Néma and Diégoune compared to those from Bazèga, Soumousso and Bankartougou (Table 6). There was no difference in root/shoot ratios among most of the provenances except those of Néma and Soumousso which were respectively lower and higher as compared to the rest (Table 6). Arbuscular mycorrhizal-root colonization levels were uniform regardless to the seed provenances. The $\mathrm{N}$ and $\mathrm{P}$ concentrations in compound leaves were significantly enhanced by the inoculation with $G$. aggregatum for all provenances. The néré plants from Bazèga showed the highest $\mathrm{P}$ and $\mathrm{K}$ content compared to other provenances (Table 6).

\subsection{Influence of tamarind seed provenances on AM response}

In tamarind plants, G. aggregatum significantly increased shoot height of plants from Tiénaba. Total dry weight was significantly increased in plants from Tiénaba and Foungioune compared to those from Kongoussi, Sondogtenga and Comin-Yanga (Table 7). Plants from Tiénaba were the most AM dependant and those from Sondogtenga showed the lowest AM dependence (Table 7). The root/shoot ratio was in general comparable for either AM or non-AM treatments regardless of the plant provenance (Table 5). The AM inoculation significantly increased the $\mathrm{N}$ content of tamarind leaves from Foungioune, Kongoussi and Comin-Yanga. $\mathrm{P}$ and $\mathrm{K}$ content were highly significant in tamarind leaves from Kongoussi compared to those of all other provenances (Tables 3 and 7). 
Mycorrhizal dependency of fruit tree provenances

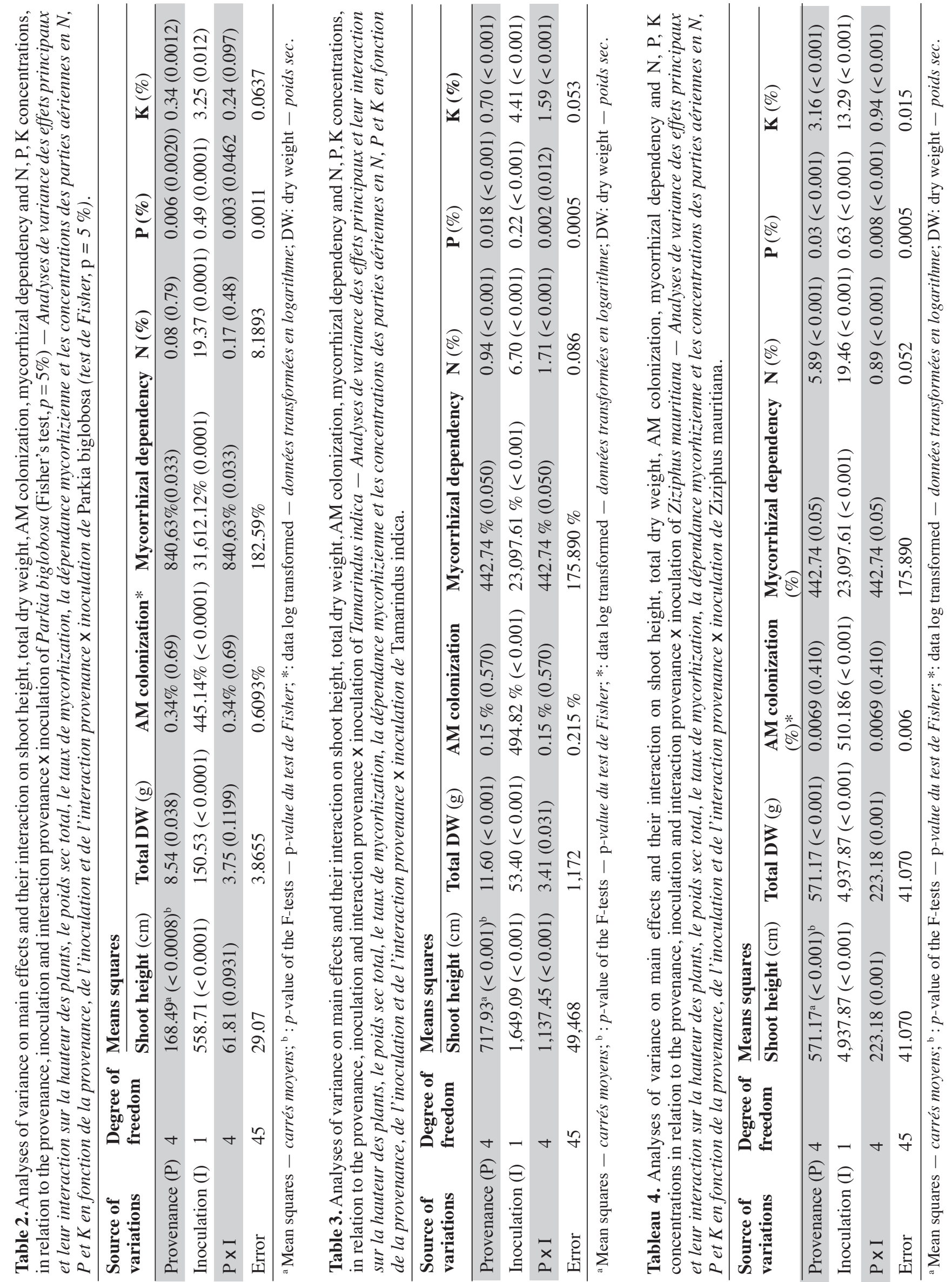


Table 5. Interaction between inoculation with Glomus aggregatum and provenance on shoot height, total dry weight, root/shoot ratio, AM colonization, leafed stems N, P and K concentrations of Parkia biglobosa, Tamarindus indica and Ziziphus mauritiana plants originating from five provenances in West Africa - Interaction entre l'inoculation avec Glomus aggregatum et la provenance sur la hauteur des plants, le poids sec total, le rapport racine/tige, le taux de mycorhization, les concentrations des parties aériennes en N, P et K des plants de Parkia biglobosa, Tamarindus indica et Ziziphus mauritiana de cinq provenances d'Afrique de l'Ouest.

\begin{tabular}{|c|c|c|c|c|c|c|c|c|}
\hline Species & Treatment & $\begin{array}{l}\text { Shoot } \\
\text { height }(\mathrm{cm})\end{array}$ & $\begin{array}{l}\text { Total dry } \\
\text { weight (g) }\end{array}$ & Root/Shoot & AM colonization $(\%)$ & $\mathbf{N}(\%)$ & $\mathbf{P}(\%)$ & $\mathbf{K}(\%)$ \\
\hline \multirow[t]{2}{*}{ Parkia } & Control & $15.45^{\mathrm{b}}$ & $4.41^{\mathrm{b}}$ & $2.42^{\mathrm{a}}$ & $0.00^{\mathrm{b}}$ & $1.17^{\mathrm{b}}$ & $0.04^{\mathrm{b}}$ & $0.90^{\mathrm{b}}$ \\
\hline & G. aggregatum & $21.12^{\mathrm{a}}$ & $7.25^{\mathrm{a}}$ & $2.57^{\mathrm{a}}$ & $89.60^{\mathrm{a}}$ & $2.14^{\mathrm{a}}$ & $0.19^{\mathrm{a}}$ & $1.30^{\mathrm{a}}$ \\
\hline \multirow[t]{2}{*}{ Tamarindus } & Control & $22.51^{\mathrm{b}}$ & $3.14^{\mathrm{b}}$ & $1.02^{\mathrm{a}}$ & $0.00^{\mathrm{b}}$ & $1.08^{\mathrm{b}}$ & $0.08^{\mathrm{b}}$ & $0.64^{\mathrm{b}}$ \\
\hline & G. aggregatum & $30.51^{\mathrm{a}}$ & $4.61^{\mathrm{a}}$ & $1.10^{\mathrm{a}}$ & 91.20 & $1.60^{\mathrm{a}}$ & $0.18^{a}$ & $1.06^{\mathrm{a}}$ \\
\hline \multirow[t]{2}{*}{ Ziziphus } & Control & $25.59^{\mathrm{b}}$ & $31.09^{\mathrm{b}}$ & $1.08^{\mathrm{b}}$ & $0.00^{\mathrm{b}}$ & $1.12^{\mathrm{b}}$ & $0.06^{\mathrm{b}}$ & $0.82^{\mathrm{b}}$ \\
\hline & G. aggregatum & $39.65^{\mathrm{a}}$ & $45.15^{\mathrm{a}}$ & $1.60^{\mathrm{a}}$ & $91.20^{\mathrm{a}}$ & $2.00^{\mathrm{a}}$ & $0.22^{\mathrm{a}}$ & $1.55^{\mathrm{a}}$ \\
\hline
\end{tabular}

In the same column and for the same species and parameter, means with a letter in common are not significantly different according to LSD Fisher protected Test - Dans la même colonne et pour les mêmes espèce et paramètre, les moyennes avec une lettre en commun ne sont pas significativement différentes selon le test LSD de Fisher.

Table 6. Effects of inoculation with Glomus aggregatum on shoot height, root/shoot ratio, mycorrhizal dependency, N, P and K concentrations of Parkia biglobosa plants originating from five provenances in West Africa - Effets de l'inoculation avec Glomus aggregatum sur la hauteur des plants, le rapport racine/tige, la dépendance mycorhizienne et les concentrations en $N, P$ et $K$ des plants de cinq provenances d'Afrique de l'Ouest de Parkia biglobosa.

\begin{tabular}{lllllll}
\hline Provenance & Shoot height $(\mathrm{cm})$ & Root/Shoot & Mycorrhizal dependency & $\mathbf{N}(\%)$ & $\mathbf{P}(\%)$ & $\mathbf{K}(\%)$ \\
\hline Bazèga & $16.87^{\mathrm{c}}$ & $2.60^{\mathrm{a}}$ & $32,34^{\mathrm{b}}$ & $1.68^{\mathrm{b}, \mathrm{a}}$ & $0.14^{\mathrm{a}}$ & $1.27^{\mathrm{a}}$ \\
Néma & $23.82^{\mathrm{a}}$ & $1.60^{\mathrm{b}}$ & $32,34^{\mathrm{b}}$ & $1.61^{\mathrm{b}}$ & $0.09^{\mathrm{d}}$ & $0.91^{\mathrm{d}}$ \\
Diégoune & $20.44^{\mathrm{b}}$ & $2.34^{\mathrm{a}}$ & $42,91^{\mathrm{a}}$ & $1.61^{\mathrm{b}}$ & $0.10^{\mathrm{d}, \mathrm{c}}$ & $1.11^{\mathrm{b}, \mathrm{c}}$ \\
Soumousso & $16.07^{\mathrm{c}}$ & $2.99^{\mathrm{a}}$ & $15,46^{\mathrm{c}}$ & $1.66^{\mathrm{a}, \mathrm{b}}$ & $0.11^{\mathrm{c}}$ & $1.02^{\mathrm{c}}$ \\
Bankartougou & $14.22^{\mathrm{c}}$ & $2.55^{\mathrm{a}}$ & $37,33^{\mathrm{a}, \mathrm{b}}$ & $1.71^{\mathrm{a}}$ & $0.13^{\mathrm{b}}$ & $1.18^{\mathrm{b}, \mathrm{a}}$ \\
\hline
\end{tabular}

In the same column and for the same parameter, means with a letter in common are not significantly different according to LSD Fisher protected Test - Dans la même colonne et pour le même paramètre, les moyennes avec une lettre en commun ne sont pas significativement différentes selon le test LSD de Fisher.

Table 7. Effects of inoculation with Glomus aggregatum on shoot height, total dry weight, root/shoot ratio, AM colonization, mycorrhizal dependency, leafed stems N, P and K concentrations of Tamarindus indica plants originating from five provenances in West Africa - Effets de l'inoculation avec Glomus aggregatum sur la hauteur des plants, le poids sec total, le rapport racine/tige, le taux de mycorhization, la dépendance mycorhizienne et les concentrations en $N$, $P$ et $K$ des plants de cinq provenances d'Afrique de l'Ouest de Tamarindus indica.

\begin{tabular}{|c|c|c|c|c|c|c|c|c|}
\hline Provenance & $\begin{array}{l}\text { Shoot } \\
\text { height }(\mathrm{cm})\end{array}$ & $\begin{array}{l}\text { Total dry } \\
\text { weight (g) }\end{array}$ & Root/Shoot & $\begin{array}{l}\text { AM colonization } \\
(\%)\end{array}$ & $\begin{array}{l}\text { Mycorrhizal } \\
\text { dependency }(\%)\end{array}$ & $\mathbf{N}(\%)$ & $\mathbf{P}(\%)$ & $\mathbf{K}(\%)$ \\
\hline Foungioune & $24.77^{\mathrm{b}}$ & $4.39^{\mathrm{a}}$ & $1.11^{\mathrm{a}}$ & $93^{\mathrm{a}}$ & $18.49^{\mathrm{a}}$ & $1.47^{\mathrm{a}}$ & $0.13^{\mathrm{b}}$ & $0.87^{b}$ \\
\hline Tiénaba & $36.84^{\mathrm{a}}$ & $4.94^{\mathrm{a}}$ & $1.03^{\mathrm{a}}$ & $88^{\mathrm{b}}$ & $20.79^{a}$ & $1.04^{\mathrm{b}}$ & $0.14^{\mathrm{b}}$ & $0.69^{c}$ \\
\hline Kongoussi & $21.06^{\mathrm{b}}$ & $3.13^{\mathrm{b}}$ & $1.11^{\mathrm{a}}$ & $92^{\mathrm{a}}$ & $13.26^{\mathrm{a}, \mathrm{b}}$ & $1.58^{\mathrm{a}}$ & $0.18^{a}$ & $1.16^{\mathrm{a}}$ \\
\hline Sondogtenga & $25.27^{\mathrm{b}}$ & $3.47^{b}$ & $1.20^{\mathrm{a}}$ & $92^{\mathrm{a}}$ & $8.68^{\mathrm{b}}$ & $1.21^{\mathrm{b}}$ & $0.10^{\mathrm{c}}$ & $0.69^{c}$ \\
\hline Comin-Yanga & $24.89^{b}$ & $3.43^{\mathrm{b}}$ & 1.09 & $91^{\mathrm{a}}$ & $14.76^{\mathrm{a}, \mathrm{b}}$ & $1.42^{\mathrm{a}}$ & $0.11^{\mathrm{c}}$ & $0.85^{\mathrm{b}}$ \\
\hline
\end{tabular}

In the same column and for the same parameter, means with a letter in common are not significantly different according to LSD Fisher protected Test - Dans la même colonne et pour le même paramètre, les moyennes avec une lettre en commun ne sont pas significativement différentes selon le test LSD de Fisher. 


\subsection{Influence of jujube seed provenances on AM response}

With jujube plants, Glomus aggregatum significantly increased shoot height, total dry weight and percentage $\mathrm{N}, \mathrm{P}$ and $\mathrm{K}$ content of inoculated plants (Table 5). In plant from Léri provenance, shoot height and total dry weight were greater than plants from other provenances (Table 8). Plants from Gonsé appeared to be the least AM dependant (Table 8). The root shoot ratio was significantly high in AM inoculated plants compared to non-inoculated ones regardless of the variety of the tree (Table 5). No significant variation was observed for AM-Root colonization between inoculated plants, but significant differences were observed between inoculated and non-inoculated plants (Tables 4 and 5). The N, P and K concentrations were significantly higher in the compound leaves of AM plants from Léri provenance (Table 8).

\subsection{Influence of fruit trees on $\mathrm{AM}$ response}

Analysis of data presented in table 1, and in tables 6 to $\mathbf{8}$, revealed that the response of the studied fruit trees to inoculation with $G$. aggregatum varies with trees and the rainfall regime of their provenance. In fact, the Parkia plants from Bazèga and Bankartougou, at 600-900 mm rainfall respond well (Tables 1 and 6), while Ziziphus plants from Léri, Bandia and Colomba respond well respectively at 900-1,000, 400-600 and 900-1,000 mm rainfall (Tables 1 and 8). Tamarindus is the only tree which responds well to the inoculation with $G$. aggregatum between $300-1,000 \mathrm{~mm}$ of rainfall. In fact, Tamarindus plants from Tiénaba and Foungioune have the highest mycorrhizal dependency respectively at $400-600$ and $900-1,000 \mathrm{~mm}$ rainfall (Tables 1 and 7).

\section{DISCUSSION}

The néré, tamarind, and jujube plants used in this study are multipurpose fruit tree species commonly grown in orchards and agroforestry systems under the arid and semi-arid climatic conditions of West Africa. They usually grow on soils characterized by low organic matter concentration with reduced available $\mathrm{P}$, making them ideal candidates for testing the potential practical applications of arbuscular mycorrhizal inoculation. The greenhouse experiment using P-deficient substrate, thus mimicking some of the indigenous soil parameters and the introduction of standard inoculum containing mycorrhizal fungi provided opportunity for comparative analysis.

Our results revealed that, regardless of seed provenance and plant species, the mycorrhizal root colonization levels were high and comparable (80$90 \%$ ) within each fruit tree species provenance. Despite these high colonization rates, shoot height and total biomass production differed significantly among provenances for the same plant species. For example, despite a high AM-root colonization level, néré plants originating from Bankartougou and plants of tamarind from Kongoussi and Sondogtenga did not display differences in biomass production compared to the non-inoculated controls. These results indicated that the level of AM-root colonization remains a weak indicator of plant growth benefits (Cavender et al., 2006; Nunes et al., 2008) because it was not always consistent with the impact AM symbiosis has on plant growth yields.

The significant enhancement of biomass production in jujube plants colonized by AM from all provenances was directly proportional with their MD values, a proportionality that did not exist in tamarind and néré plants. These results corroborate previous reports

Table 8. Effects of inoculation with Glomus aggregatum on shoot height, total dry weight, mycorrhizal dependency, leafed stems $\mathrm{N}, \mathrm{P}$ and $\mathrm{K}$ concentrations of Ziziphus mauritiana plants originating from five provenances in West Africa - Effets de l'inoculation avec Glomus aggregatum sur la hauteur des plants, le poids sec total, la dépendance mycorhizienne et les concentrations en $N$, $P$ et $K$ des parties aériennes des plants de Ziziphus mauritiana de cinq provenances d'Afrique de l'Ouest.

\begin{tabular}{lllllll}
\hline Provenance & Shoot height $(\mathrm{cm})$ & Total dry weight $(\mathrm{g})$ & Mycorrhizal dependency $(\%)$ & $\mathbf{N}(\%)$ & $\mathbf{P}(\%)$ & $\mathbf{K}(\%)$ \\
\hline Bandia & $31,07^{\mathrm{b}}$ & $37,20^{\mathrm{b}}$ & $30,64^{\mathrm{a}}$ & $0,77^{\mathrm{e}}$ & $0,10^{\mathrm{d}}$ & $0,57^{\mathrm{d}}$ \\
\hline Léri & $41,36^{\mathrm{a}}$ & $46,86^{\mathrm{a}}$ & $32,45^{\mathrm{a}}$ & $2,15^{\mathrm{a}}$ & $0,20^{\mathrm{a}}$ & $1,66^{\mathrm{a}}$ \\
Dahra & $27,13^{\mathrm{c}}$ & $32,63^{\mathrm{c}}$ & $27,59^{\mathrm{a}}$ & $1,27^{\mathrm{d}}$ & $0,13^{\mathrm{c}}$ & $1,12^{\mathrm{c}}$ \\
Colomba & $30,01^{\mathrm{b}, \mathrm{c}}$ & $35,15^{\mathrm{b}, \mathrm{c}}$ & $30,30^{\mathrm{a}}$ & $1,89^{\mathrm{b}}$ & $0,12^{\mathrm{c}}$ & $1,33^{\mathrm{b}}$ \\
Gonsé & $32,89^{\mathrm{b}}$ & $38,39^{\mathrm{b}}$ & $18,21^{\mathrm{b}}$ & $1,71^{\mathrm{c}}$ & $0,17^{\mathrm{b}}$ & $1,25^{\mathrm{b}}$ \\
\hline
\end{tabular}

In the same column and for the same parameter, means with a letter in common are not significantly different according to LSD Fisher protected Test - Dans la même colonne et pour le même paramètre, les moyennes avec une lettre en commun ne sont pas significativement différentes selon le test LSD de Fisher. 
which found that these three fruit trees responded differently to AM inoculation (Bâ et al., 2000; Guissou et al., 2001; Solaiman et al., 2008; Johnson et al., 2010; Schultz et al., 2010). The high MD values for jujube were previously obtained and known to vary according to the AM fungal species used as inoculum (Mathur et al., 2000; Smith et al., 2000; Urcelay et al., 2003). Mycorrhizal dependency values cannot be predicted neither by root colonization measurements nor by root architecture (Guissou et al., 1998) even though several authors stated that the length and the density of root hairs are good indicators of plant species or cultivars MD (Simard et al., 2002; Collier et al., 2003; Sorensen et al., 2005; Janos, 2007; Johnson et al., 2010). Nevertheless, our results demonstrate, for the first time, that the MD of some Sahelian fruit trees varied according to their provenance and as such corroborate previous data obtained with Acacia (Duponnois et al., 2003; Lesueur et al., 2005; Belay et al., 2013), and Dalbergia sissoo Roxb. DC. (Devagiri et al., 2001) leguminous trees.

Interestingly, regardless of AM inoculation, there was a difference in $\mathrm{N}, \mathrm{P}$ and $\mathrm{K}$ absorption by plants particularly with tamarind (Tiénaba and Kongoussi provenances) and jujube (Léri and Gonsé provenances). When the two provenances and G.aggregatum inoculation are investigated, an additional N, P and K uptake takes place. It is then possible to suggest that tamarind and jujube from those provenances may have developed ecological plasticity in order to better adapt themselves to poor nutrient soil conditions. In almost all provenances (except tamarind from Tiénaba), AM inoculation significantly improved the N, P and $\mathrm{K}$ absorption compared to non-AM fruit trees. These findings are consistent with published data on the enhanced nutrient uptake observed in mycorrhizal plants (Fitter et al., 2011; Smith et al., 2011; Jiang et al., 2013) partly due to the existence of an extraradical hyphal network capable of exploring a greater soil volume (Simard et al., 2002; Marulanda et al., 2003; Schnepf et al., 2008).

An interesting element, in terms of mineral absorption, can be observed between species and provenances. The $\mathrm{P}$ levels in compound leaves of $\mathrm{AM}$ inoculated jujube from Colomba, Bandia and Dahra were respectively 7,10 and 6 times higher in control plants than $\mathrm{P}$ concentrations in the other provenances of Léri and Gonsé where only a two-fold increase was observed. In that particular case, the most efficient provenances in $\mathrm{P}$ uptake coincided with the most AM-dependent one. On the other hand, with néré plants, a reducing effect of the AM inoculation was observed in the $\mathrm{N}$ and $\mathrm{K}$ uptake from Tiénaba. This is probably due to growth dilution effect brought about by increased plant biomass in AM-plants compared to non-AM plants (Ahiabor et al., 1994).

\section{CONCLUSIONS}

In conclusion, the MD and mineral nutrient absorption potential may vary depending on the plant species and their provenance. Our results revealed the existence of substantial provenance variation, which can be utilized to initiate tree improvement program of the species and large-scale fruit production in orchards and other agroforestry systems. To be successful in practical applications of these findings, further investigations are now required to evaluate the competitiveness of the G. aggregatum isolate with the AM fungi population of indigenous soils of West Africa, particularly in Burkina Faso and Senegal including Mali and Niger and to reveal the underlying mechanisms.

\section{Acknowledgements}

This article is published in the memory of our regretted colleague Dr. Tiby Guissou. Dr. Guissou is grateful to the International Foundation for Science (IFS, Sweden, and grant $\mathrm{N}^{\circ} \mathrm{D} / 2460-2$ ) for its financial support to this research, to Dr Jules Bayala (ICRAF, West and Central Africa Regional Office, Research Unit SD1 \& 6), to Dr Patrice Savadogo (ICRAF/ICRISAT West and Central Africa) for revision of this manuscript, and to Pr. Stephen Machado at Oregon State University for English-language assistance.

\section{Bibliography}

Ahiabor B.D. \& Hirata H., 1994. Characteristic responses of three tropical legumes to inoculation of two species of VAM fungi in andosol soils with different fertilities. Mycorrhiza, 5, 63-70.

Akinnifesi F.K. et al., 2004. Domesticating priority miombo indigenous fruit trees as a promising livelihood option for smallholder farmers in southern Africa. Acta Hortic., 632, 15-30.

Akinnifesi F.K. et al., 2006. Towards the development of miombo fruit trees as commercial tree crops in southern Africa. For. Trees Livelihoods, 16, 103-121.

Ambé A.G., 2001. Les fruitiers sauvages comestibles des savanes guinéennes de Côte d'Ivoire: état des connaissances par une population locale, les Malinké. Biotechnol. Agron. Soc. Environ., 5(1), 43-58.

Atangana A.R. et al., 2001. Domestication of Irvingia gabonensis: 1. Phenotypic variation in fruit and kernels in two populations from Cameroon. Agroforest. Syst., 53, 55-64.

BâA.M. et al., 2000. Functional compatibility of two arbuscular mycorrhizae with thirteen fruit trees in Senegal. Agrofor. Syst., 50, 95-105.

Belay Z., Vestberg M. \& Assefa F., 2013. Diversity and abundance of arbuscular mycorrhizal fungi associated with acacia trees from different land use systems in Ethiopia. Afr. J. Microbiol. Res., 7(48), 5503-5515. 
Cavender N. \& Knee M., 2006. Relationship of seed source and arbuscular mycorrhizal fungi inoculum type to growth and colonization of big bluestem (Andropogon gerardii). Plant Soil, 285, 57-65.

Chandra K.K., Kumar N. \& Chand G., 2010. Studies on mycorrhizal inoculation on dry matter yield and root colonization of some medicinal plants grown in stress and forest soils. J. Environ. Biol., 31, 975-979.

Collier S.C., Yames C.T. \& Herman R.P., 2003. Mycorrhizal dependency of Chihuahuan desert plants is influenced by life history strategy and root morphology. J. Arid. Environ., 55, 223-229.

Declerck S., Strullu D.G. \& Plenchette C., 1996. In vitro mass-production of the arbuscular mycorrhizal fungus, Glomus versiforme, associated with Ri T-DNA transformed carrot roots. Mycol. Res., 100, 12371242.

Devagiri G.M., Dhiman R.C., Singh Y.P. \& Patil S.K., 2001. Seed source dependent variation in mycorrhizal colonisation and nutrient uptake in Dalbergia sissoo seedlings. J. Trop. For. Sci., 13, 246-257.

Duponnois R. \& Plenchette C., 2003. A mycorrhiza helper bacterium enhances ectomycorrhizal and endomycorrhizal symbiosis of Australian Acacia species. Mycorrhiza, 13, 85-91.

Fitter A.H., Helgason T. \& Hodge A., 2011. Nutritional exchanges in the arbuscular mycorrhizal symbiosis: implications for sustainable agriculture. Trends Cell. Biol., 25, 68-72.

Franzel S., Akinnifesi F.K. \& Ham C., 2007. Setting priorities among indigenous fruit species: examples from three regions in Africa. In: Akinnifesi F.K. et al., eds. Indigenous fruit trees in the tropics: domestication, utilization and commercialization. Nairobi: World Agroforestry Centre; Wallingford, UK: CAB International Publishing.

Guissou T. et al., 1998. Responses of Parkia biglobosa (Jacq.) Benth., Tamarindus indica L. and Ziziphus mauritiana Lam. to arbuscular mycorrhizal fungi in a phosphorus-deficient sandy soil. Biol. Fertil. Soils, 26, 194-198.

Guissou T. et al., 2001. Effets des mycorhizes à arbuscules sur la tolérance à un stress hydrique chez quatre arbres fruitiers Balanites aegyptiaca (L.) Del.,Parkia biglobosa (Jacq.) Benth., Tamarindus indica L. et Ziziphus mauritiana Lam. Sécheresse, 12, 121-127.

Janos D.P., 2007. Plant responsiveness to mycorrhizas differs from dependence upon mycorrhizas. Mycorrhiza, 17, 75-91.

Jiang W., Guangqian G. \& Ding Y., 2013. Influence of arbuscular mycorrhizal function growth and mineral element absorption of Chenglu hybrid bamboo seedlings. Pak. J. Bot., 45(1), 303-310.

John M.K., 1970. Colorimetric determination of phosphorus in soil and plant materials with ascorbic acid. Soil Sci., 100, 214-220.
Johnson D. et al., 2010. Plant genotypic diversity does not beget root-fungal species diversity. Plant Soil, 336, 107111.

Jung S.C., Martinez-Medina A., Lopez-Raez J.A. \& Pozo M.J., 2012. Mycorrhiza-induced resistance and priming of plant defenses. J. Chem. Ecol., 38, 651-664.

Kungu J. et al., 2008. Effect of vesicular arbuscular mycorrhiza (VAM) fungi inoculation on coppicing ability and drought resistance of Senna spectabilis. Pak. J. Bot., 40, 2217-2224.

Leakey R.R.B. et al., 2005. Agroforestry tree products (AFTPs): targeting poverty reduction and enhanced livelihoods. Int. J. Agric. Sustainability, 3, 1-23.

Lesueur D. \& Duponnois R., 2005. Relations between rhizobial nodulation and root colonization of Acacia crassicarpa provenances by an arbuscular mycorrhizal fungus, Glomus intraradices Schenck \& Smith or an ectomycorrhizal fungus, Pisolithus tinctorius Coker \& Couch. Ann. For. Sci., 62, 467-474.

Lynch J.P., 2007. Roots of the second green revolution. Aust. J. Bot., 55, 1-20.

Manoharan P.T. et al., 2010. Influence of AM fungi on the growth and physiological status of Erythrina variegata Linn. grown under different water stress conditions. Eur. J. Soil Biol., 46, 151-156.

Marulanda A., Azcon R. \& Luiz-Lozano J.M., 2003. Contribution of six arbuscular mycorrhizal fungal isolates to water uptake by Lactuca sativa plants under drought stress. Physiol. Plant., 119, 526-533.

Mathur N. \& Vyas A., 2000. Influence of arbuscular mycorrhizae on biomass production, nutrient uptake and physiological changes in Ziziphus mauritiana Lam. under water stress. J. Arid Environ., 45, 191-195.

McGonigle T.P. et al., 1990. A new method which gives an objective measure of colonization of roots by vesiculararbuscular mycorrhizal fungi. New Phytol., 115, 495501.

Murphy J. \& Riley J.P., 1962. A modified single solution method for the determination of phosphate in natural waters. Ann. Chem. Acta, 27, 31-35.

Nunes J.L., da S. Souza P.V.D., de Marodin G.A.B. \& Fachinello J.C., 2008. Inoculation of arbuscular mycorrhizal fungi in peach rootstock cv Okinawa. Rev. Bras. Frutic., 30, 1100-1106.

Ozgonen H., Akgul D.S. \& Erkilic A., 2010. The effects of arbuscular mycorrhizal fungi on yield and stem rot caused by Sclerotium rolfsii Sacc. in peanut. Afr. J. Agric.Res., 5(2), 128-132.

Phillips J.M. \& Hayman D.S., 1970. Improved procedures for clearing roots and staining parasitic and vesiculararbuscular mycorrhizal fungi for rapid assessment of infection. Trans. Br. Mycol. Soc., 55, 158-161.

Plenchette C., Fortin J.A. \& Furlan V., 1983. Growth responses of several plant species to mycorrhizae in a soil of moderate P-fertility. I: Mycorrhizal dependency under field conditions. Plant Soil, 70, 199-209. 
Plenchette C., Clermont-Dauphin C., Meynard J.M. \& Fortin J.A., 2005. Management of arbuscular mycorrhizal fungi in cropping systems. Can. J. Plant Sci., 85, 31-40.

Querejeta J.I. et al., 2003. Differential response of a C13 and water use efficiency to arbuscular mycorrhizal infection in two arid land woody plant species. Oecologia, 135, 510-515.

SAS, 1990. SAS procedure guide. Version 6 edition. Cary, NC, USA: SAS Institute Inc.

Schnepf A., Roose T. \& Schweiger P., 2008. Impact of growth and uptake patterns of arbuscular mycorrhizal fungi on plant phosphorus uptake: a modelling study. Plant Soil, 312, 85-99.

Schultz C.J., Kochian L.V. \& Harrison M.J., 2010. Genetic variation for root architecture, nutrient uptake and mycorrhizal colonisation in Medicago truncatula accessions. Plant Soil, 336, 113-128.

Simard S.W., Jones M.D. \& Durall D.M., 2002. Carbon and nutrient fluxes within and between mycorrhizal plants. In: van der Heijden M.G.A. \& Sanders I.R., eds. Mycorrhizal ecology. Berlin, Germany: Springer-Verlag.

Smith F.A., Jakobsen I. \& Smith S.E., 2000. Spatial differences in acquisition of soil phosphate between two arbuscular mycorrhizal fungi in symbiosis with Medicago truncatula. New Phytol., 147, 357-366.

Smith S.E. \& Smith F.A., 2011. Roles of arbuscular mycorrhizas in plant nutrition and growth: new paradigms from cellular to ecosystem scales. Annu. Rev. Plant Biol., 62, 227-250.
Solaiman Z.M. \& Abbott L.K., 2008. Influence of arbuscular mycorrhizal fungi, inoculum level and phosphorus placement on growth and phosphorus uptake of Phyllanthus calycinus under jarrah forest soil. Biol. Fertil. Soils, 44, 815-821.

Sorensen J.N., Larsen J. \& Jakobsen I., 2005. Mycorrhiza formation and nutrient concentration in leeks (Allium porrum) in relation to previous crop and cover crop management on high P soils. Plant Soil, 273, 101-114.

Sousa C.S. et al., 2013. Arbuscular mycorrhizal fungi within agroforestry and traditional land use systems in semiarid Northeast Brazil. Acta Scientiarum Agron., 35(3), 307-314.

St-Arnaud M. \& Elsen A., 2005. Interactions with soil borne pathogens and non-pathogenic rhizosphere microorganisms. In: Declerck S., Strullu D.G. \& Fortin J.A., eds. Root-organ culture of mycorrhizal fungi. New York, NY, USA: Springer Verlag, 217-231.

Steel R.G.D. \& Torrie J.H., 1980. Principles and procedures of statistics, a biometrical approach. New York, NY, USA: MacGraw-Hill Book Co.

Urcelay C. \& Diaz S., 2003. The mycorrhizal dependence of subordinates determines the effect of arbuscular mycorrhizal fungi on plant diversity. Ecol. Lett., 6, 388391.

(49 ref.) 